\title{
ARCHIBALD PITCAIRNE AND NEWTONIAN MEDICINE
}

\author{
by
}

\section{ANITA GUERRINI*}

In the spring of 1692 , Isaac Newton entertained a visitor in his rooms in Trinity College, Cambridge. This was in itself unusual for the reclusive scientist; and, in addition, he entrusted to the visitor, Archibald Pitcairne, the fruit of his latest work on alchemy, chemistry, and the theory of matter, the essay 'De natura acidorum'. Over a period of several days, the two conversed on topics related to the essay, or, rather, Pitcairne asked questions which Newton answered. Immediately following his departure, Pitcairne sent copies of the essay, including notes of his interviews, to his friends. ${ }^{1}$

Who was Archibald Pitcairne, that Newton should have entrusted such an important document to him? At the time of his visit, he was on his way to Leiden to assume the professorship of the practice of medicine at that city's university. An Edinburgh physician and a prominent member of scientific circles there, Pitcairne was a close friend of the mathematician David Gregory. Although he had published little, the Leiden appointment signalled his growing reputation as a medical theorist. Pitcairne's ideas grew out of the iatromechanical school, but he also explicitly connected his ideas with those of Newton. His successors and followers accepted this connection. In this paper I shall examine the relationship between Pitcairne's ideas on medicine and physiology and Newton's concept of the microcosm before the publication of the Opticks in 1704. I have argued elsewhere that, at least for the period of the 1690s, "Newtonianism" should be narrowly defined as an intellectual movement based on the understanding and use of Newton's ideas. ${ }^{2}$ I shall attempt in this paper to measure Pitcairne's work in this period by this criterion.

Pitcairne was born in Edinburgh in 1652, the son of a merchant-magistrate who was also a minor laird. He matriculated at the University of Edinburgh in 1668. Soon rejecting the study of divinity, he took the standard arts course, graduating MA in 1671. By then, he had decided to study law, and went to Paris to continue his studies. Apparently he found the law course there not to his liking, for he took up with a group of Scots medical students, and began to accompany them on their hospital rounds. The elder Pitcairne objected to this agreeable activity and called his son home to * Anita Guerrini, PhD, Program in the History of Science and Technology, University of Minnesota. Minneapolis, Minnesota 55455, USA.

${ }^{1}$ H. W. Turnbull et al. (editors), The correspondence of Issac Newton, vol. 3, Cambridge University Press, 1961, pp. 205-241. Pitcairne's visit and the transmission of his manuscript to Gregory is described on pp. 212-213, n. 1 .

2 Anita Guerrini, 'The Tory Newtonians: Gregory, Pitcairne and their Circle', J. Br. Stud., 1986, 25: 288-311. 


\section{Archibald Pitcairne and Newtonian medicine}

Edinburgh. It was probably at this time, in the mid-1670s, that Archibald Pitcairne made the acquaintance of the precocious David Gregory. ${ }^{3}$

Gregory, born in 1659 , was the scion of a family noted for its scientific achievements. His uncle, James Gregory, professor of mathematics at the University of Edinburgh, encouraged his interest in mathematics, and on his death in 1675, his papers, including his correspondence with Newton, passed to his nephew. Pitcairne had begun to study mathematics during his sojourn in Edinburgh, which ended with his return to France in 1675 , and it is possible that he met David Gregory in the context of James Gregory's mathematics lectures. The younger Gregory encouraged Pitcairne's mathematical talents, and the latter produced some work on infinite series, a topic of mutual interest, during this period. The same period perhaps provided the origin of Gregory's lifelong interest in medicine. ${ }^{4}$

Pitcairne was in France from 1675 until August 1680, when he received his MD from the University of Rheims. It is likely, however, that he returned to Edinburgh periodically during this time, for upon receiving his degree he at once stepped into the circle of Edinburgh's best-known physicians. His mathematical bent made him a natural member of the circle of physicians around Robert Sibbald (1641-1722). This group, which met fortnightly to discuss scientific issues, was the predecessor to the Royal College of Physicians of Edinburgh, formed at the end of 1681, with Pitcairne among the youngest of its members. ${ }^{5}$ The ever-active Sibbald also persuaded the university to found a chair of medicine in 1685 , with himself as professor. He agitated for a true medical faculty, with a group of examiners; as a result, two additional professorships were created, one of them going to Pitcairne. The professors were provided "convenient rowmes" but "no Cellaries from ye good town, nor from ye sd University." Pitcairne does not seem to have delivered any lectures at the university during the $1680 \mathrm{~s}^{6}$

Pitcairne's wife died some time before 1687; in that year, he was lodging with Gregory, who had become professor of mathematics at the University of Edinburgh in $1683 .^{7}$ This was a period of intense intellectual activity for both men. Although Gregory's medical lectures and notebooks date from the ensuing decade, he became

\footnotetext{
${ }^{3}$ Biographical accounts of Pitcairne include: Charles Webster, An account of the life and writings of the celebrated Dr Archibald Pitcairne, Edinburgh, Gordon \& Murray, 1781; Biographia Britannica, vol. 5, pp. 3359-3366; Dictionary of Scientific Biography (DSB), vol. 11, pp. 1-3; Dictionary of National Biography (DNB), vol. 15, pp. 1221-1223; R. Peel Ritchie, The early days of the Royall Colledge of Physitians, Edinburgh, Edinburgh, G. P. Johnston, 1899, pp. 159-189; Catalogue of the graduates of the University of Edinburgh, Edinburgh, Neill, 1858, p. 100. All these accounts are vague concerning events before 1680; it is difficult to determine precisely when Pitcairne met David Gregory.

${ }^{4}$ For Gregory, see A. G. Stewart, The academic Gregories, Edinburgh, Oliphant, Anderson, \& Ferrier, 1901 , ch. 4, pp. 52-76; Biog. Brit., vol. 4, pp. 2365-2372; DSB, vol. 5, pp. 520-522; P. D. Lawrence and A. G. Molland, 'David Gregory's inaugural lecture at Oxford', Notes Rec. R. Soc. Lond., 1970, 25: 143-144; Christina Eagles, 'The mathematical works of David Gregory', PhD dissertation, University of Edinburgh, 1977, pp. 17-21. For Gregory's interest in medicine, see his medical notes in British Library, Add. MS 29, 243, and below. His father, the laird of Kinnairdie in Banffshire, was an amateur physician of some repute: $D N B$, vol. 8, pp. 537-538.

${ }^{5}$ Ritchie, op. cit., note 3 above, pp. 54-56, 66; W. S. Craig, History of the Royal College of Physicians of Edinburgh, Oxford, Blackwell, 1976, pp. 61, 65-66.

${ }^{6}$ Ritchie, op. cit. note 3 above, pp. 171-172. Cf. Alexander Grant, The story of the University of Edinburgh, London, Longmans, Green, 1884, vol. 1, pp. 217-219; Alexander Bower, The history of the University of Edinburgh, Edinburgh, Oliphant, Waugh, \& Innes, 1817, vol. 1, p. 376.
} 
acquainted at this time, if not before, with Pitcairne's cases and with the Italian iatromechanists, especially Borelli and Bellini, whom the physician was studying deeply. Gregory received a copy of Newton's Principia soon after its publication in July 1687, and he immediately began his commentary on it, the massive Notae in Newtoni Principia, with which Pitcairne was therefore well acquainted. ${ }^{8}$

In 1688, Pitcairne issued his first publication, an essay entitled, Solutio problematis de historicis; seu de inventoribus dissertatio, which contains some hints of his new theory of medicine, sparked by his study of Newton. It was accompanied by a first fruit of Gregory's study of Newton, his account of his new method of quadratures. Neither Gregory nor Pitcairne mentioned Newton by name, however. ${ }^{9}$ Pitcairne had been greatly impressed by the work of Borelli and Bellini, especially the latter's De urinis et pulsibus (1683), which he continued to cite frequently. Newton's mathematical physics, which far surpassed Borelli's in sophistication, inspired Pitcairne in his search for a mathematical medicine both by its method and by its conclusions. ${ }^{10}$

Most medical men regarded the discovery of the circulation of the blood as the greatest scientific event of the seventeenth century, leading to a reformation of all physiological theory. In the Solutio, Pitcairne dealt with the claims of a certain M. Dacier, who asserted that Hippocrates had known all along about the theory of the circulation. Such a claim was not new. Pitcairne's defence of Harvey's priority in the discovery of the theory of circulation emphasizes the modernity of Harvey's method in making that discovery. Although Harvey had been generally regarded and admired as an experimentalist, Pitcairne claimed that his method, which he extolled as the true method of science, was not experimental but mathematical. Alluding to Borelli's use of mathematical method in biology, and perhaps also to Newton's method in the Principia, Pitcairne commented: "We ought to make a nice Distinction between those things which are demonstrated by their own Evidence, and those that are so by the Light of other things, that is, between such things whose Evidence is such, that when we have once understood their Proofs, we cannot conceive them to be otherwise; and those things which are neither demonstrated from themselves, nor other things." Harvey's discovery fell into the former category; and Pitcairne implied that a true demonstration must be mathematical in form, as indeed, he asserted, his own treatise was. Although one "of a moderate Skill in the Elements of Geometry" could reason wrongly, the result of such reasoning would be "plainly opposite to all the Principles of that Science". Because Hippocrates did not understand the true method of sciencegeometry-he could not have discovered the circulation, Pitcairne concluded, quite

\footnotetext{
${ }^{7}$ Pitcairne later told Richard Mead that he had been lodging with Gregory in 1687: Richard Mead, $O$ f the influence of the sun and moon on humane bodies ..., London, R. Wellington, 1712, pp. 43-44. On Gregory's appointment see Bower, op. cit., note 6 above, vol. 1, pp. 306-307; vol 2, p. 82.

${ }^{8}$ Gregory to Newton, 2 September 1687 , in Newton, op. cit., note 1 above, vol. 2, 1960, p. 484. Copies of Gregory's Notae include Christ Church, Oxford, Gregory MS 131, and University Library Edinburgh, MS Dc.4.35.

9 John Craig was astonished at Gregory's omission of Newton's name; see Craig to Colin Campbell, 30 January 1688/89, in Newton, op. cit., note 1 above, vol. 3, 1961, p. 9.

${ }^{10}$ For Pitcairne's study of Borelli and Bellini, see Anita Guerrini, 'Newtonian matter theory, chemistry, and medicine, 1690-1713', PhD dissertation, Indiana University, 1983, pp. 57-62; T. M. Brown, The mechanical philosophy and the "animal economy", New York, Arno, 1981, pp. 194-211. Cf. his account of Pitcairne in ch. 4, which differs significantly from mine (see below).
} 
apart from textual evidence that he did not do so. " The Solutio amounted to a harsh attack on the prevailing Hippocratic doctrines and methods. Originally he intended to accompany it with the Epistola Archimedis ad regem Gelonem, a savage satire of the Scots Presbyterians and medical methodists, rather than with Gregory's mathematical treatise. Even when published alone, the Solutio, which Pitcairne may have delivered as one of the monthly discourses at the Royal College of Physicians of Edinburgh, could not have been very palatable to its physicians, Hippocratic or otherwise. ${ }^{12}$

To Pitcairne, as to other iatromechanists of the period, secretion provided the best physiological example for mechanistic explanation. In his memoranda, Gregory provided a succinct outline of Pitcairne's ideas on this topic. At about the same time as his friend moved to Leiden, Gregory accepted the Savilian professorship of astronomy at Oxford. Among the prerequisites for the chair was the possession of a doctoral degree; he chose to take an MD, which required a set of theses on a text of Galen. Perhaps referring to these theses, Gregory wrote in his memoranda, "if it be necessary that I emitt Theses at Act. I am resolved to have them de secretione Animali. and for that Cause to look over Wharton de glandulis, Coles de secretione Animali, Bayle, and Willis if they have written any thing or any thing thats newer, to destroy the parts indifferently figured as naively geometrical and either to establish the mutual attraction of homogeneous Bodys, or the meer different bigness of pores and for the ancient termes to read Senerti institutiones medicinae." 13 In the event, Gregory perhaps decided that such a task was too arduous, for the theses submitted were drawn from his Edinburgh lectures on optics and did not mention secretion. ${ }^{14}$

A few months later, however, secretion played a prominent role in Pitcairne's inaugural lecture at Leiden in April 1692. The predominant error of current medical thinking, he said, was the interpretation of secretion; and this error was based on faulty scientific method, as he had stated in the Solutio. He rejected the search for ultimate causes pursued by the "philosophical sects": "Our knowledge of Things is confined to the Relations they bear to one another, and the Laws and Properties of Powers, which enable them to produce changes in some things, and to become altered by other things." It is possible that these "Powers" (vires) were forces similar to what he could have inferred from Newton's essay 'De natura acidorum'; he had met with Newton only two months earlier. In the present state of knowledge, Pitcairne continued, the

\footnotetext{
11 Archibald Pitcairne, Solutio problematis de historicis: seu de inventoribus dissertatio, Edinburgh [n.p.], 1688, translation in Pitcairne, The works, trans. George Sewell and J. S. Desaguliers, London, E. Curll et al., 1715 , pp. 137, 150. All quotations are from this translation, somewhat modified for clarity. I have compared it with the Latin: Archibald Pitcairne, Elementa medicinae physico-mathematica . . . item ejusdem opuscula medica, Venice, A. Bortoli, 1740.

12 Archibald Pitcairne, Epistola Archimedis ad regem Gelonem [n.p., n.d.]. A manuscript copy of this essay dated 1688, in a hand resembling David Gregory's, is University Library Edinburgh, MS La. II. 36. On the attitude of the collegiate physicians, see Andrew Cunningham, 'Sydenham versus Newton: the Edinburgh fever dispute of the 1690 s between Andrew Brown and Archibald Pitcairne', in W. F. Bynum and V. Nutton (editors), Theories of fever from antiquity to the enlightenment, London, Wellcome Institute for the History of Medicine, 1981 , p. 94.

${ }_{13}$ Royal Society, Gregory MS 247, f. 80; the page is not dated. On Gregory's assumption of the Savilian chair, see Lawrence and Molland, op. cit., note 4 above, pp. 145-146. The works Gregory refers to are: Thomas Wharton, Adenographia (1656); William Cole, De secretione animali cogitata (1674); Daniel Sennert, Institutiones medicae (1611); François Bayle's De usu lactis, the third of his Dissertationes medicae tres (1670), and the works of Thomas Willis.

14 David Gregory, 'Tres lectiones cursoriae', Aberdeen University Library, MS 2206/8, ff. 1-48.
} 
nature of these "Powers" could not be known. Such knowledge would in any case be "of no advantage" to a physician, whose duty was "to weigh and consider the Powers of Medicines and Diseases as far as they are discoverable by their Operations, and to reduce them to Laws." This was strictly analogous to Newton's method in the Principia, especially in Book II, in which he had studied the effects of gravity without reference to its cause, and Pitcairne said as much: "Physicians ought to propose the Method of Astronomers as a Pattern for their Imitation." 15

All knowledge comes from sense experience, Pitcairne continued, and opinions should not be regarded. He advocated a Baconian collection of medical observations, from which physicians could induce "Laws and Properties" after a proper ordering of the collected facts. But Pitcairne's main emphasis was on Newton's method: "it [is not] unreasonable to suppose, that lesser Bodies, which are the Objects of Medical Enquiries, are subject to the same Laws that Astronomers have discovered in the Greater. The Nature of all Bodies is certainly the same, and every Body is capable of being changed into the Body of another of any Kind whatsoever; and by consequence all Bodies, of whatever Magnitude or Minuteness, are liable to the common Effects of Motion, or Change." 16 Here are three principal elements of Newton's theory of matter, as gleaned from the Principia and 'De natura acidorum': the analogy of the microcosm to the macrocosm, the possibility of limitless transmutation, and the inertness of matter, which was independent of force and activity. He could indeed have derived all these elements from the Principia alone; his comment on transmutation is taken almost verbatim from Newton's 'Hypothesis III'. 'De natura acidorum' reiterated these views and made clear Newton's commitment to a short-range force analogous to gravity. Yet in this lecture Pitcairne never mentioned Newton by name, nor the concept of attraction. ${ }^{17}$

On the basis of the method he described, Pitcairne went on to reject every current physiological concept: substantial forms, ferments, the horror vacui, subtle fluids, the Cartesian "Poetical Machinary [sic]" of matching pores and particles, sympathies and antipathies-he discarded all in a sweeping renovation of the house of physic. His refutation of the Cartesians was particularly sharp, perhaps reflecting Newton's similar concerns in the early 1690s; and the theory of secretion was his main weapon. Pitcairne stated, "I can prove that there is no Fermentation in the Glands of a Human Body, that all the Pores and all the Orifices are of a similar Figure, and therefore that the Diversity of Figures, and Ferments introduced by the Adherents of a Sect, is of no manner of Use in the Theory or Practice of Physick." The "infamous Mark of Uncertainty", he promised, was about to be removed from medicine for good. ${ }^{18}$

\footnotetext{
15 Archibald Pitcairne, Oratio, qua ostenditur medicinam ab omni philosophorum secta esse liberam ... Leiden, A. Elsevier, 1692, translation in Pitcairne, op. cit., note 11 above, pp. 11-12, 13. Cf. Lester King, The philosophy of medicine: the eighteenth century, Cambridge, Mass., Harvard University Press, 1978, pp. 113-114. He prefers a weaker translation of vires as "phenomena" or "data" to contrast with Galenic causae or essences.

16 Pitcairne, op. cit., note 11 above, p. 17.

17 Isaac Newton, Philosophiae naturalis principia mathematica, edited by A. Koyré and I. B. Cohen, Cambridge University Press, 1972, vol. 2., p. 552n. Cf. J. E. McGuire, 'Transmutation and immutability: Newton's doctrine of physical qualities', Ambix, 1967, 14: 69-95.

18 For Newton's activities in the early 1690s, see R. S. Westfall, Never at rest, Cambridge University Press, 1980, ch. 11, passim. Pitcairne, op. cit., note 11, p. 19.
} 
Pitcairne's inflammatory lecture was received with great applause at Leiden; on the same day, the university governors voted to increase his salary. ${ }^{19} \mathrm{He}$ wasted no time in fulfilling his promise to place medicine on the track of scientific respectability. In a series of "dissertations" presented and published at Leiden in 1693, he presented his new "iatromathematics" in which he paired Bellini and Newton in a slightly uneasy union. These dissertations were "exercitii gratia", staged performances at which selected students responded to the master's exposition. They supplemented those Pitcairne read as professor, and unlike the statutory lectures, the dissertations were rushed into print. ${ }^{20}$ Andrew Cunningham has stated that the dissertations "constituted a progressive, chapter by chapter, demolition of Cartesian explanations and their replacement by what Pitcairne believed to be Newtonian ones." 21 Cunningham, in his excellent account of the Edinburgh fever debates of the 1690s in which Pitcairne played a prominent role, is perhaps too willing to take Pitcairne's self-evaluation as a Newtonian at face value. It is true that, much as Pitcairne admired Bellini, his dissertations offered several criticisms of the Italian school of iatromechanism. But when Bellini and Newton disagreed, Pitcairne did not invariably choose Newton, at least not the Newton of 'De natura acidorum'.

He delivered the first of these dissertations, 'On the circulation of the blood through the minutest vessels of the body', in January 1693. It was published, in Leiden, the following June. Pitcairne opened with the standard assertion that the circulation of the blood was the key to life. Once more, Harvey assumed the mantle of the first iatromathematician. As Pitcairne had earlier hinted, and as Bellini had emphasized, secretion was the critical effect of the circulation. He wrote: "For the Circulation of the Blood is not more necessary for the Preservation of Life, than its perpetual Supplies of the Secretion of abundance of Fluids, and its Disposal of them into different Parts; and the Causes of most Diseases are to be look'd for in the Disorder of this Secretion, either as it is encreased or diminished."22

In his explanation of the mechanism of secretion Pitcairne rejected in turn the explanations of Willis, the Helmontian iatrochemists, and the Cartesian mechanists, including Bellini, because, he said, all contradicted the central fact of circulation. The notion that fluids were separated from the blood in secretion-as all current theories required-was problematic in the context of a circulating blood: "Altho' moreover many Fluids are separated from the Blood, which are never restored to it again, and so cannot be said to circulate; yet there is a Necessity for some Motion of theirs dependent upon the Circulation of the Blood, so that if their Motion ceases entirely, this too [i.e. the blood] must sink into either an immediate or a gradual stagnation." 23 Pitcairne

${ }^{19}$ G. A. Lindeboom, 'Pitcairne's Leyden interlude described from the documents', Ann. Sci., 1963, 19: 280-282.

${ }^{20}$ R. W. Innes Smith, English-speaking students of medicine at the University of Leyden, Edinburgh, Oliver \& Boyd, 1932, pp. 115-116. Three of the four respondents were Scots: George Hepburn twice and James Johnston. The dissertations were all originally published in 1693 .

${ }^{21}$ Cunningham, op. cit., note 12 above, p. 89. Cf. Robert Schofield, Mechanism and materialism, Princeton University Press, 1970, pp. 49-50. He bases his more conservative estimate of Pitcairne's Newtonianism on a reading of his lectures, not of the dissertations.

${ }_{22}$ Archibald Pitcairne, Dissertatio de motu sanguinis per vasa minima, Leiden, A. Elsevier, 1693, translation in Pitcairne, op. cit., note 11 above, p. 34.

${ }^{23}$ Ibid., p. 33. 


\section{Anita Guerrini}

agreed that the blood's pressure caused the continued motion of the body fluids. He rapidly dismissed the theories of Willis and the Helmontians, whose "ferments" would quickly be washed away by the circulating blood, and spent most of his time criticizing the sieves or strainers of the Cartesians. He pointed out that if the blood was indeed a heterogeneous fluid, composed of particles of differing sizes and shapes, secretion by means of a strainer mechanism would be very difficult, it not impossible. Smaller particles would be able to pass through the holes intended for larger ones; large particles could block small pores; and even if the particles were differentiated by geometric forms, several different shapes could pass through a given pore-a cone, for example, could pass through a pore intended for a sphere. Moreover, with geometric solids, not only size and shape but position became crucial, since a cube, for example, could only pass through an exactly-sized square hole in a limited number of positions. Pitcairne gave two equations, borrowed from Huygens, to demonstrate that a selective straining out of particles from the blood, or from any heterogeneous fluid, was impossible. Either all the particles would pass through a given pore, or none of them would. ${ }^{24}$

In fact, Pitcairne added, the nature of a heterogeneous fluid such as the blood made the arguments of the Cartesians irrelevant. In his notes appended to Newton's 'De natura acidorum", Pitcairne had recorded Newton's comments on secretion. Newton defined fluidity as "the smallness, and thus the separability of parts, understood as parts of the last composition", that is, minima naturalia, although art may reduce substances further. He continued, "Urine is secreted through small passages in the kidneys because it is attracted to those passages and has affinity with them." He then directly confronted the Cartesian theory: "Difference of shape of pores makes no difference [in secretion] because the pores are much wider than the particles of liquid entering them." 25 In his letter to Boyle of February 1679, Newton had in addition denied that shape determines sociability between particles: "When any metal is put into common water, ye water cannot enter into its pores to act on it $\&$ dissolve it. Not yt water consists of too gross parts for this purpose, but because it is unsociable to metal. For there is a certain secret principle in nature by wch liquors are sociable to some things \& unsociable to others." 26

Pitcairne's account of secretion, published fifteen months after his meeting with Newton, reflected the latter's ideas up to a point. The passage is worth quoting at length:

Whoever attentively considers how great a Portion of our blood is of a watry Subtilty, or rather of a watry Fluidity, not to say entirely watry; and to what extent Water, or any thing of an aqueous Fluidity and Gravity, can by degrees and by a gentle Heat easily be rarified, and separated into even the minutest Particles; Or if he considers the Nature of a Fluid; he will soon allow, that the blood which flows thro' our Vessels by the Force impressed upon it by the Motion of the Heart, may be separated into Particles much more minute than the Orifices which it meets with in its Course. And yet every one of these separated Particles may be a Fluid, and perhaps a compound of other heterogeneous Fluids; for every Fluid ought to be thought of as consisting of an infinite Smallness of Parts, which however in different Fluids requires a different Force to cause a

24 Ibid., pp. 42, 45-48.

${ }^{25}$ Newton, op. cit., note 1 above, vol. 3, pp. 207-208, 211.

${ }^{26}$ Ibid., vol. 2, pp. 291-292. 


\section{Archibald Pitcairne and Newtonian medicine}

Separation of those Parts. So that the minutest Solid parts of the Fluids are not secreted in the Vessels and Glands, but the Fluids themselves, tho' sometimes but in a small Quantity. (For it is not to be imagined, that the Force impressed by the Motion of the Heart and the Arteries is so great, as to be able to separate the minutest Parts of the smallest Fluid from an Union with the rest; for if so, we should meet with Volatile Salts instead of Blood, dispersed thro' all the greater Arteries.) But it is evident that Fluids do not require any peculiar or regular Figure, since they can adapt themselves to any Figure, and penetrate any Orifice, provided that the impelling Powers are strong enough to break the Cohesion of the Fluid at the Entrance of the Orifice. From whence it follows, that if Fluids are secreted from the Blood of an Animal in a State of Fluidity, there is no occasion for any peculiar Configuration of the receiving Orifice, but any will serve, if it be but large enough; neither are the Figures of the minutest Parts of the secreting Fluid of any consequence in the Performance of the Works of Secretion. ${ }^{27}$

Newton had described the hierarchical nature of visible matter, which was composed of molecules of ascending orders of magnitude and complexity, in several passages in 'De natura acidorum' ${ }^{28}$ Pitcairne followed this description, but he seems to have been reluctant to define the nature of the cohesion of these clusters of particles. He implied a non-mechanical cohesion in the passage above, since the mere force of the heart could not break it; but he never stated this unequivocally. Nor did he follow Newton in claiming the existence of a sociability between the pore and the fluid; such a relationship he at most implied.

Pitcairne's objection to such a multiplication of entities as attractive forces entailed was strictly methodological, and the method employed was, he believed, Newton's own. The Scot had described this method in his inaugural lecture. In the dissertation 'On the circulation of the blood...', his demonstration of his own theory and his attempts to refute rival explanations rested almost entirely on logical grounds. He disproved the strainer theory, as we have seen, on the grounds of mathematical improbability. Following the lead of Borelli, Pitcairne presented mathematical method as the only certain method in dealing with submicroscopic entities, such as the unobserved and, in contemporary conditions, unobservable particles of the blood. In his essay, Pitcairne noted that the laws of hydraulics dictated that the secretory tubules be cylindrical, thereby overturning a major component of the competing theory. But his main argument was logical: "And this Simplicity, and those few Postulata's which distinguish our Hypothesis, is a genuine Evidence of that Truth, which the Greatest and Best Geometrician had been pleased to affix to it." The greatest and best geometrician was probably God, but he mentioned Newton a few lines down. He attributed to Newton the "geometrical method" of the first 'Hypothesis' of the Principia: the simplest explanation-in Pitcairne's case, one shape of secretory orifice rather than several-was best. ${ }^{29}$

Pitcairne went on to praise medicine for its amenability to geometry, and elaborated his own theory of secretion which featured numerical proportions to demonstrate an essentially mechanistic scheme. In avoiding the use of occult attractions for which he had castigated the chemists, he turned to yet another mechanism. He divided the secretions into "grosser" and "thinner" fluids which passed through appropriately sized, rather than shaped, orifices. He required that the "Number and Bulk" of the

\footnotetext{
27 Pitcairne, op. cit., note 11 above, pp. 43-44.

28 Newton, op. cit., note 1 above, vol. 3, pp. 207, 211.

29 Pitcairne, op. cit., note 11 above, p. 51-52.
} 


\section{Anita Guerrini}

vessels leading to larger orifices be in such a proportion to those of smaller orifices that all the thinner fluids could not pass at once through the larger passages. This was much less precise, and certainly as open to question, as the Cartesians' geometrical spaces, but Pitcairne added something which the Cartesian theory could not allow: the arteries secreted the thinner fluids, the veins the grosser. ${ }^{30}$

Pitcairne's "iatromathematics" allowed him, in the dissertation 'On the circulation of the blood', to reject other theories of secretion. He concluded that secretion could only depend on the sizes of the secretory "pores" and not on their shapes, and that these sizes could only be very generally classified as "larger" or "smaller". He could not state more with accuracy on the basis of mathematical proportion and probability, but his conclusion told the reader little about physiology. Therefore he went on to add the detail that the veins and arteries separated the grosser and thinner fluids respectively. He made no attempt at this time to confirm this statement with, for example, measurement of the diameters of the corresponding vessels. His characterization of Harvey indicates that experiment and indeed precise measurement were not major aspects of his scientific method.

'On the circulation of the blood' was the most "Newtonian" of Pitcairne's dissertations at Leiden, and the "Newtonianism" consisted primarily of methodological references and secondarily of references to Newton's hierarchical theory of matter. In the second dissertation, 'Upon the motion which reduces the aliment in the stomach to a form proper for the supply of the blood', delivered in April 1693, he rejected well-known iatrochemical explanations of digestion in favour of a strictly mechanistic account in which the muscular motion of the stomach transformed food into chyle without chemical additions. Digestion, said Pitcairne, was not a transmutation, and he referred in passing to Newton's 'Hypothesis III" to define true transmutation. Pitcairne again supported his argument with logic rather than experiment. He sought "a proper Cause ... the most simple and natural force." In Newtonian fashion, he did not comment on the origins of that force which caused the motion of the stomach. Such a motion, he believed, provided a far simpler explanation than one involving chemical ferments; therefore, by his methodological dicta, it must be the correct explanation. ${ }^{31}$

His two last Leiden dissertations, delivered in April and June of 1693, were much more conventionally mechanistic and made no reference to Newton. Internal evidence suggests Pitcairne may have written them between 1683 and 1687 and recycled them following the success of his earlier efforts. In these dissertations, as in those earlier delivered, he emphasized his methodological differences with other physicians, and once more, Occam's razor was his primary logical tool. As before, he suspected all chemical explanations of submicroscopic events and rejected hypothetical entities such as ferments. 32

\footnotetext{
${ }^{30}$ Ibid., pp. 56-57.

31 Archibald Pitcairne, Dissertatio de motu, quo cibi in ventriculo rediguntur ad formam sanguini reficiendo idoneam, Leiden, A. Elsevier, 1693, translation in Pitcairne, op. cit., note 11, pp. 113, 106.

32 Archibald Pitcairne, Dissertatio de causis diversae molis . . ., Leiden, A. Elsevier, 1693; and Dissertatio de circulatione sanguinis in animalibus genitis et non genitis, Leiden, A. Elsevier, 1693, translations in Pitcairne, op. cit., note 11 above, pp. 61-101, 164-187. The most recent work cited by Pitcairne in these essays was Johann Bohn's Circulo anatomico-physiologus, published in 1686.
} 


\section{Archibald Pitcairne and Newtonian medicine}

The regular lectures Pitcairne delivered at Leiden as professor in 1692-3 were only published in $1717 .{ }^{33}$ In the first of these, he succinctly outlined the theory of matter which underlay his dissertations in the course of refuting current Cartesian theories. Newton's influence is apparent, but this was not the Newtonian matter theory of the Opticks of a decade hence. Rather, Pitcairne formulated his own notion, drawing on the Principia and 'De natura acidorum'. Following the methodological rules of his dissertations, he would make, he said, only mathematically verifiable statements, and he did not comment on the relationship between such statements and physical reality. He based his first proposition, that matter is infinitely divisible, on geometrical principles. He went on to state as axiomatic several basic tenets of Newtonian physics: although motion must exist, it is not innate to matter; inertial states are preserved; all bodies are heavy. Equal specific gravity of two bodies, he added, indicated "the like number of equal parts" between the two; "those Bodies which do not equally gravitate under the same Dimensions, do not contain the same number of equal Portions of Matter." From this Pitcairne concluded, with Newton, that "an Etherial subtle Matter filling the Pores of all Bodies, and freely passing thro' them, is a mere figment."34 Medicine, said Pitcairne, could no longer rely upon Hippocratic empiricism; he agreed with the Cartesian mechanists that medicine must include the application of correct scientific theory. He concluded, however, "I do advise indeed all diligently to consider the Principles of the Cartesian Philosophy, and to compare them with those of Democritus, so far as Geometry will conduct them . .. as a Qualification for the Study of medicine, I rather recommend an Acquaintance with the Mathematicks, than with the Philosophy which is now so much in Esteem." 35 He embodied the success of such a course of study.

Yet having dismissed Descartes, Pitcairne did not fully welcome Newton in his place. Attractions had no role in his mechanistic scheme of physiology. The heartbeat, the cause of circulation, furnished his central mechanism; the blood was only alive while it circulated, and all body functions derived from it. The body was composed of "Canals and Fluids", and the hydraulics of this arrangement provided the proper realm of physic. His method dictated his theory; since only measurable, geometrizable objects existed, Pitcairne rejected as a hypothetical entity anything not potentially measurable, whether or not he actually performed any measurement. He attributed "temperaments", for example, to changes in the canals and fluids, thereby making them measurable, real attributes. It followed that he rejected all chemical explanations. "Innate heat" was caused not by a ferment but by the attrition of the particles of the blood during circulation, in the course of which they collided with the vascular walls and with each other. It was therefore dependent upon the motion of the heart. As in much of Pitcairne's work, the underlying metaphor came from astronomy: the heart causes life-evidenced in vital heat-by its beat, as the sun causes motion in the

\footnotetext{
${ }^{33}$ Archibald Pitcairne, Elementa medicinae, London, W. Innys, 1717, translated by John Quincy as The philosophical and mathematical elements of physick, London, A. Bell \& J. Osborn, 1718. All quotations are from this translation. Brown for some reason refers to these as the "Edinburgh lectures" (op. cit., note 10 above, p. 233) and says they are later in time than the Leiden dissertations, but there is no evidence for this assertion.

34 Pitcairne, op. cit., note 33 above, pp. 3-6.

35 Ibid., pp. 6-8.
} 
universe by means of its gravity. He drew an analogy between gravity and the heartbeat, not, as Newton had in 'De natura acidorum', between gravity and local, short-range attractions. ${ }^{36}$

Pitcairne derived function from structure; from the shape of the arteries, he determined that the vascular circulation defined life itself in his dissertation on 'The circulation of the blood in born animals and embrio's' ${ }^{37}$ From function, he derived design. In the circulation of the blood and the motion of the heart he found evidence of divine intervention in a manner reminiscent of Newton's account of gravity; as we have seen, Pitcairne found the heartbeat and gravity analogous. No chemical, thermal, or mechanical reason could be found for the motion of the heart; neither ferments nor "animal heat" could produce its alternate systole and diastole. Therefore, he concluded, God must be directly responsible. The existence of circulation in the embryo substantiated his view that "No animal is ever produced mechanically". 38 Newton's explanation of planetary motion in his 1693 letters to Richard Bentley was similar: "So then Gravity may put the Planets into Motion, but without the divine Power it could never put them into such a circulating Motion as they have about the Sun; and therefore, for this, as well as other Reasons, I am compelled to ascribe the Frame of this System to an intelligent Agent." ${ }^{39}$ Although Pitcairne was probably not acquainted with these letters, he could have read Bentley's Boyle lectures, the last of which, published in May 1693, expounded the same theme. Since Pitcairne mentioned neither Bentley nor Newton in this regard, this is only surmise. But a year later he wrote to his friend Robert Gray, "I have desired Gregorie to procure me a scheme of $\mathrm{Mr}$ Newton's divine thoughts (I hope yee'l not laugh) that I may write a demonstration for our religion: but this will be a tale of two drinks. I am confident tho that better things may be said to that purposs than hitherto has been said." He added in a postscript, "I am serious in seeking ane account of $\mathrm{Mr}$ Newtons thoughts anent differences in religion, for I am truly resolved to doe something that way." Gray might well have found the idea of the high-church Jacobite Pitcairne seeking religious wisdom from the low-church Whig Newton rather laughable. Pitcairne's "demonstration", if he wrote it, has not survived. . $^{40}$

Had Pitcairne adhered strictly in his works to his own dictum-that only mathematical statements are possible about invisible entities-he could not have said anything about actual animal structure or function, indeed, about medicine. In fact, he said quite a lot about medicine. But, particularly in his Leiden medical lectures (rather than the "dissertations"), he rarely ventured beyond the iatromechanics of Bellini. On the basis of mechanics, mathematics, and mathematical method, he freely rejected chemical and vitalistic explanations, but he did not have enough information to devise

${ }^{36}$ Ibid., pp. 8, 10-11, 20-21, 25, 30.

${ }^{37}$ Pitcairne, op. cit., note 11 above, pp. 165, 167-170, 171-186.

38 Ibid., pp. 166-167.

39 Isaac Newton, Four letters . . to Doctor Bentley, 1756, reprinted in I. B. Cohen (editor), Isaac Newton's letters and papers on natural philosophy, Cambridge, Mass., Harvard University Press, 1958, p. 198. The quotation is from Letter II, dated 17 January 1692/3.

${ }_{40}$ Pitcairne to Robert Gray, 24 October 1694, BL Sloane MS 3216, f. 158v, printed in W. T. Johnston (editor), The best of our oune: letters of Archibald Pitcairne, 1652-1713, Edinburgh, Saorsa Books, 1979. pp. 19-20. 
a completely new system of "iatromathematics", a difficulty which he fully recognized. Bellinian explanations, of which he was often critical, were the nearest he could approach to a Newtonian, fully mathematized physiology of forces analogous to gravity. Pitcairne faced the same problems as had Newton concerning the theory of matter, and indeed they were dealing with different aspects of the same problem, the application of the established laws of the macrocosm to the microcosm. Both men took it for granted that the one was analogous to the other, but atoms could not be observed as planets could. In 'De natura acidorum', the very general statements Newton made about the submicroscopic world could not be pressed beyond the most elementary level without flying off into remote speculation.

Pitcairne's intellectual dilemma is evident in the pages of his dissertations; he believed that Newton's "mathematical way" was the correct road to truly scientific explanation, but, in medicine as in matter theory, mathematics could, he thought, as yet only refute other theories without making any convincing positive statements about physical reality. In the mid-1690s, after his return to Edinburgh from Leiden, Pitcairne tried to provide experimental and mathematical support for his conclusions. In 1694-5, he campaigned for the provision of cadavers for regular dissections, and to his friend Robert Gray he described several dissections he had performed himself. In the autumn of 1694 he commented, "I have laid aside De ictero till wee get some bodyes to look into ... I want the measure of the capacitie of some arteries without which all is conjecture." In addition, he claimed to be working on a treatise 'De veribus attractionibus partis sanguinis', which indicates that his reading of 'De natura acidorum' did not go unheeded. In the same letter, he expressed doubts about his discourse on the cure of fevers, which, as Cunningham has noted, offended the Royal College of Physicians of Edinburgh as much by its arrogance as by its conclusions. ${ }^{41}$ This is a very different Pitcairne from the brash Leiden professor.

Yet these attempts at experimental justification were, apparently, unsatisfactory, for in Pitcairne's few subsequent publications he explicitly ruled out the possibility of knowledge of short-range attractions. In his 'Some observations concerning womens monthly courses', probably written in the late 1690 s, he stated, "Neither shall we here consider any Attracting Forces, either of the blood, or of the Vessels ... we shall only see what the force of Gravity has to do in the Solution of this Question." 42 In his work 'On the division of distempers' he forcefully argued that the nature of the microcosm was, and would remain, unknown. ${ }^{43}$

Despite his professed intentions, therefore, Pitcairne did not develop a Newtonian theory of medicine, a "principia medicinae" in which the human body would be analysed in the same way Newton had analysed the macrocosm in the Principia, and he seems to have recognized the impossibility of such a task within the context of contemporary knowledge. This failure was not, as Brown has argued, because mechanism fails as an explanatory device in physiology. ${ }^{44}$ However we may feel about

\footnotetext{
${ }^{41}$ Pitcairne to Robert Gray, 23 September 1694, BL Sloane MS 3216, ff. 164-165, printed in Johnston, op. cit., note 40 above, pp. $18-19$.

42 Archibald Pitcairne, Observationes quaedam de fluxu menstruo, translation in Pitcairne, Works, op. cit.. note 11 above, p. 228.

${ }^{43}$ Archibald Pitcairne, De divisione morborum, translation in ibid., pp. 266-267.
} 


\section{Anita Guerrini}

iatromechanics today, it remained the idiom for thinking about physiology until well into the eighteenth century. Pitcairne's understanding of Newton was much more sophisticated than Brown - who does not mention 'De natura acidorum'-allows; and it is in 'De natura acidorum' and Newton's concept of short-range attraction that we find the key to the possibility of a Newtonian medicine. Pitcairne concluded, however, that the door which this key unlocked was not yet to be found.

Nonetheless, much as the Italian iatromechanists had inspired his own work, Pitcairne served as inspiration for a new generation of physicians in Britain. He left Leiden in the summer of 1693 never to return, for reasons which remain unknown. ${ }^{45}$ During his short sojourn there, he left a deep impression on a number of students. Several of these men, including George Cheyne, William Cockburn, and Richard Mead, were his pupils in Leiden; others, such as James Keill and John Freind, learned of him through David Gregory. These men in turn attempted, with varying success, to apply Newtonian principles to medical theory. Their movement grew in strength after the turn of the eighteenth century, when Newton left Cambridge for London, became president of the Royal Society, and divulged some of his thoughts on the theory of matter in the Opticks. A period of great activity, culminating in James Keill's 1708 Account of animal secretion, saw the publication of more than twenty books and papers by members of this group, and they benefited both socially and financially from their association with Newton. ${ }^{46}$ Pitcairne, however, persisted in his contention that a theory of physiology based on the concept of short-range attraction remained wholly speculative, and he castigated Keill's work as "word for word Bellini's if yee'l put the word Cohaesion for Attraction", 47 even while he criticized William Cockburn for not paying attention to the "doctrin of mutual attraction". 48

Pitcairne remained in Edinburgh, where he engaged in the series of disputes with the Royal College of Physicians of Edinburgh between 1695 and 1700 described by Cunningham. ${ }^{49} \mathrm{He}$ began to lecture on medical theory at the new school of medicine at the University of Edinburgh some time after its foundation in $1705 .^{50}$ Although he wrote few new works, his Leiden dissertations were reissued twice before his death in 1713 , and they were translated into English and printed again two years later. ${ }^{51}$

Was Pitcairne a Newtonian? In his close attention to Newton's method, ideas of causality, and theory of matter Pitcairne showed himself more closely acquainted with

\footnotetext{
${ }^{44}$ Brown, op. cit., note 10 above, pp. 235-237. George Cheyne referred to "principia medicinae theoreticae mathematicae" in his Essay concerning the improvements in the theory of medicine, published in 1702.

${ }^{45}$ Lindeboom, op. cit., note 19 above, pp. 280-282. Cunningham, op. cit., note 12 above, p. 90; Webster, op. cit., note 3 above pp. 17, 20.

${ }^{46}$ On these men, see Guerrini, op. cit., note 10 above.

${ }^{47}$ Pitcairne to Gray, 27 December 1709, BL Sloane MS 3216, f. 174, printed in Johnston, op. cit., note 40 above, p. 57.

${ }^{48}$ BL Sloane MS 3198, f. 94r. This is a commentary by Pitcairne on Cockburn's 'Solution of the problem for determining the doses of purging and emetick medicines', Phil. Trans., 1705, 24: 2119-2122.

${ }^{49}$ Cunningham, op. cit., note 12 above, p. 94 and passim; Craig, op. cit., note 5 above, pp. 408-419; Ritchie, op. cit., note 3 above, pp. 170-179.

${ }_{50}$ Manuscript student notes survive from 1712-13: Wellcome Institute, London, MS 2451, John Fullerton, 1713-14; Library, University of British Columbia, Vancouver, Josiah Holmes, 1712.

51 The dissertations were first printed in a collected edition in Rotterdam in 1701, and reprinted in Edinburgh in 1713.
} 
Newton's thought than many, or most, of his contemporaries. In his published work he used Newtonian ideas and arguments, if not wholly Newtonian accounts, to explain such functions as secretion. In so doing he introduced these ideas, in a medical context, to an entire generation of physicians, ${ }^{52}$ among them Herman Boerhaave. Yet in comparison, for example, to the works of his friend David Gregory, his works seem only marginally Newtonian, an attempt to wedge traditional medicine into a Procrustean bed of physical science. As I have argued, he recognized this difficulty. Pitcairne nonetheless thought of himself as a disciple of Newton, and knowledgeable contemporaries, including, apparently, Newton himself, concurred in this estimation.

\section{ACKNOWLEDGEMENTS}

Research grant SES 82-04747 from the National Science Foundation, a grant-in-aid from the Graduate School, Indiana University, and a Mellon Fellowship of the American Philosophical Society provided material assistance for which the author is grateful.

\footnotetext{
52 See Anita Guerrini, 'James Keill, George Cheyne, and Newtonian physiology, 1690-1740', J. Hist. Biol., 1985, 18: 247-266.
} 